[総説]

\title{
照射食品検知法の現状と新たな展開
}

\author{
関口正之* \\ （地独）東京都立産業技術研究センター（１１35-0064＼cjkstart東京都江東区青海 2-4-10）

\section{Current Status of Detection Methods of Irradiated Foods and Recent Information}

\author{
Sekiguchi Masayuki * \\ Tokyo Metropolitan Industrial Research Technology Institute, 2-4-10 Aomi, Koto-ku, Tokyo 135-0064, Japan
}

Key words: Irradiated Foods (照射食品), Detection Methods (検知法), Quarantine inspection (検疫検査), European Standards (EN) Test Methods（ヨーロッパ標準試験方法），Self Inspection（自主検査）

\section{1.はじめに}

食品が商品として流通するという現実に目を向け ると, 消費者は生産者でないが故にその価值だけで なく, 安全・安心にかかわる情報に重きをおかざる を得ないという立場にある。情報の送り手とその信 頼性や伝達の迅速性に注視しながらも，一方で情報 に左右されやすいという消費者の感性が，時に風評 という二次情報を生むことにも配慮すべきである。 消費者へ届けられる食品は, 原料の生産から加工・ 流通の過程で, 農薬や殺菌剤の残留, 害虫や寄生虫 の侵入や病原菌, 食中毒菌, 腐敗微生物など色々な 微生物による污染のリスクがあり, 健康被害を受け る可能性がある。また, 保存環境により, 鮮度も生 産された時点から次第に低下し, 最終的には自ら持 つ分解䤃素や微生物, 酸化などの化学的作用により, 風味や食感も変化し当初の品質と商品価值は失われ る。扎ししくて安全・安心な食品は, 生産者, 製造 者の高い意識とともに，適正な生産や衛生に対する 管理技術，保存技術，そして適正な情報の開示と表 示により支えられている。

近年，環太平洋パートナーシップ協定 (TPP) や

*連絡先：sekiguchi.masayuki@iri-tokyo.jp
経済連携協定（EPA）などの国際的な協定が進展し つつあり, SPS (衛生植物検疫) に関するルールも 協議されており，様々な食品の国内への流通が増加 すると考えられる。食品の品質を維持するための処 置，また病原菌などによる健康被害を事前に防ぎ， 病害虫の防疫対策などから殺菌，消毒，殺虫などの 処理の重要性は高まっている。食品への放射線照射 技術も上記のような食品の品質保持や健康被害を防 ぐ目的で使用される。国によって許可品目や許容線 量，食品表示などに関する法規制が異なるため，輸 出国で適法に製造されたものでも，我が国に輸入さ れる場合を含め国際的な流通に打いては，違法な食 品となる可能性がある。製造や輸入を行う食品事業 者は，食品の履歴と法規制に充分注意しなければな らないし，自主検査の必要性も高まっている。食品 の保存や殺菌，芽止めや検疫処理への放射線の照射 利用とその法規制などの歴史的な経緯，国際的な状

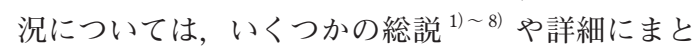
められた専門書 ${ }^{9)}$ が出版されており，全体像を理 解する上で大変参考となる。

\section{2. 輸入食品の監査指導体制と照射食品の検知}

\section{1 輸入食品の監査指導体制と照射食品}

我が国の輸入食品の検査指導体制は，平成 15 年 
の「食品衛生に関する監視指導の実施に関する指 針（平成 15 年 8 月 29 日)」(厚生労働省告示第 301 号）に基づき厚生労働省が毎年作成する輸入食品監 視指導計画に示されている。平成 26 年度について は, 平成 26 年 3 月 28 日付け食安発 0328 第 1 号に 基づき平成 26 年度輸入食品監視指導計画が示され た ${ }^{10)}$ 。また, 平成 20 年には監視指導の一環として 輸入加工食品の自主管理に関する指針（ガイドライ ン）(平成 20 年 6 月 5 日付け食安発第 0605001 号) も示されている ${ }^{11)}$ 。その考え方は武田の報告 ${ }^{12)}$ に 詳しく説明されており，概要は，Table 1のような ものになる。輸出国での衛生管理や法規制の実態に ついての情報と, 輸入時に輸入者が提出する輸入届 出による書類審査, 次に輸入品の一定数について実 施される検疫所で行うモニタリング検査などの科学 的な検查, そして国内流通時には各都道府県が行う 収去検查や販売者の自主検查が行われるが，いずれ も公定試験方法に基づき実施することが原則であ
る。モニタリング検査や他の行政検査, 各自治体が 行う収去検査などで不合格となった食品は，その時 点で各種の行政措置を受けると共に，検査命令を受 け，企業の負担で解除まで長期にわたり検査の実施 を強いられる。食品安全に対する企業責任の大きさ とともに逸脱した際のペナルティの高さをも自覚し なければ，企業の存続も立ちゆかなくなる。

欧州における食品への放射線照射の基本的な考え 方は，香辛料やハーブなどの食品を污染する微生物 或いは微生物の代謝産物が公衆衛生に度々有害な影 響を与えてきていること，またそのような微生物に よる污染と感染を，有毒な残留生成物を生じるエチ レンオキサイド（酸化エチレンガス）などによる燻 蒸処理を使用するのではなく，その代替えとして放 射線照射が公衆衛生の利益になるという視点に基づ いている。この視点は医療機器や医薬品, ラボウェ アや包装材料・容器の滅菌における滅菌方法の変遷 とも一部共通する点がある。それらの滅菌処理に

Table 1 輸入食品の監視指導体制

\section{[輸入時の検査等]}

輸入届出による確認 (検疫所)

·輸出国における衛生管理, 証明書の発給, 輸出前検査等

(輸入時検査体制)

過去の違反事例，輸出国の情報（海外における食品安全情報等），原料・製造情報を配慮

1.モニタリング検査（国が費用負担，試験結果の判明を待たずに輸入手続可）

2. 他の行政検査（国が費用負担，初回輸入時の検査，不適格食品等の確認，輸送途中で事故が発生した場合） (検査結果)

$\bigcirc$ 合 格 $\rightarrow$ 輸入可

$\bigcirc$ 不合格 ${ }^{\text {a) }} \rightarrow$ 回収 ·廃棄・積み戻し又は食用外用途転用，輸入時検查強化，違反事例の公表等

3 . 検査命令 (輸入者が費用負担 : 法違反の可能性が高いと見込まれる輸入食品等)

$\rightarrow$ 登録検查機関で輸入の都度，検査を実施し，適法と判断されるまで輸入手続き不可 ${ }^{\mathrm{b})}$ 。

4. 自主検査（輸入者が費用負担 : 初回輸入時や定期的な輸入時に衛生確保義務の観点より実施)

[国内流通時の検査等]

1. 都道府県等監視指導計画に基づく都道府県等の収去検査

2 . 販売者等の自主検査

(検查結果)

$\bigcirc$ 合 格 $\rightarrow$ 消費者へ供給

$\bigcirc$ 不合格 ${ }^{a)} \rightarrow$ 回収 ·廃棄等, 輸入時検査強化, 違反事例の公表

a) 不合格の場合は国内で所定の対応をした他に，輸出国において，再発防止対策（原因究明及び対応する新たな規 制，管理体制の整備，検査の強化等）が実施され，二国間協議や必要に応じ現地調査，輸入時検査による再発防 止対策の有効性を確認することになる。

b）検査命令においても，a）の対応による場合の他， 2 年間違反事例がない或いは， 1 年間新たな違反事例がなく検 査命令の実施件数が 300 件以上ある場合, 違反品の食品が輸入される恐れがないと判断し検査命令が解除される。 
は, 我が国の薬局方で標準法として収載されている 加熱滅菌 (高圧蒸気滅菌や乾熱滅菌), 酸化エチレ ンガス滅菌，ろ過滅菌，放射線滅菌（ $\gamma$ 線照射，電 子線照射), 高周波滅菌が使用される ${ }^{13)}$ 。最近では 過酸化水素滅菌や過酸化水素低温プラズマ滅菌と いった新しい滅菌法も収載されている ${ }^{14)}$ 。そこで 求められる特性は, (1)処理後に残留する殺菌剂及び 生成する副生物が人体に対する毒性を持たないこ と，(2)プラスチック製のディスポーザブル製品が多 いため常温で処理できること, (3)処理パラメーター が少なく安定した管理ができること, (4)作業者への 懪露や環境への負担が少ないことなどである。従 来, 医療機器滅菌の大半は, 処理が穏和で経済性で 優れていたことから酸化エチレンガス滅菌が使用さ れていたが, 残留毒性と滅菌作業者の被曝, 環境へ の排出規制の強化，処理パラメーターの管理とバリ
デーションへの負担が大きくなったことから，現在 では多様な素材から構成されるものや他の方法では 材質劣化が大きく代替えができない製品に使用する 方向にある。殺菌郕の残留を極度に嫌う製品や，残 留が大きくかつ除去の困難な製品，吸湿性を持つ粉 体やエマルジョン，ゲル，複雑な構造を持ちエチレ ンオキサイドガスや蒸気が浸透しない製品やろ過滅 菌で対応できない製品については放射線滅菌（ガン マ線，電子線）の利用が進んでいる。

\section{2 照射食品の公定試験法}

照射食品を科学的に検査する手段として，欧州共 同体（EC）では 1996 年から 2004 年にかけて 10 種 類の検査方法をヨーロッパ標準分析法に制定してい る ${ }^{15), 16)}$ (Table 2)。メンバー国に打ける許可品目と 最大許容線量（総平均線量）も欧州共同体官報 ${ }^{17)}, 18$

Table 2 放射線照射食品を検出するための EN 標準分析法 ${ }^{15)}$

\begin{tabular}{|c|c|c|}
\hline 法 & CEN 規格番号 & $\begin{array}{c}\text { 分析対象 (線量值：kGy） } \\
\text { (限界線量：標準法として妥当性検証済み) }\end{array}$ \\
\hline $\begin{array}{l}\text { (1)炭化水素 (HC) } \\
\text { 脂質の分解生成物 }\end{array}$ & $\begin{array}{l}\text { EN1784 (1996), } \\
\text { (2003 改訂) }\end{array}$ & $\begin{array}{l}\text { 鶏肉 }(0.5) \text {, 豚肉 }(0.5) \text {, 牛肉 }(0.5), \text { アボガ } \\
\text { ド }(0.3) \text {, マンゴ }(0.3) \text {, パパイア }(0.3) \text {, カ } \\
\text { マンベールチーズ }(0.5)\end{array}$ \\
\hline $\begin{array}{l}\text { (2) 2-アルキルシクロブタノン (2-ACB) } \\
\text { 脂質の特定の分解生成物（DCB, TCB） }\end{array}$ & $\begin{array}{l}\text { EN1785 (1996), } \\
\text { (2003 改訂) }\end{array}$ & $\begin{array}{l}\text { 鶏肉 }(0.5) \text {, 豚肉 }(0.5) \text {, 液体全卵 (1), カ } \\
\text { マンベールチーズ }(1) \text {, サケ (1) }\end{array}$ \\
\hline $\begin{array}{l}\text { (3)骨の ESR 測定 } \\
\text { ラジカルの検出 }\end{array}$ & EN1786 (1996) & $\begin{array}{l}\text { 鶏肉 }(0.5) \text {, 肉 }(0.5) \text {, 魚, (マス) }(0.5) \text {, 力 } \\
\text { エルの足 }(0.5)\end{array}$ \\
\hline $\begin{array}{l}\text { (4)セルロースの ESR 測定 } \\
\text { ラジカルの検出 }\end{array}$ & $\begin{array}{l}\text { EN1787 (1996), } \\
\text { (2000 改訂) }\end{array}$ & $\begin{array}{l}\text { パプリカ粉末 (5), ピスタチオナッツの殼 (2), } \\
\text { イチゴ (1.5) }\end{array}$ \\
\hline $\begin{array}{l}\text { (5)糖結晶の ESR 測定 } \\
\text { ラジカルの検出 }\end{array}$ & EN13708 (2001) & $\begin{array}{l}\text { 乾燥パパイア }(3), \text { 乾燥マンゴ }(3), \text { 乾燥1 } \\
\text { チジク (3), 干しブドウ (3) }\end{array}$ \\
\hline $\begin{array}{l}\text { 66熱ルミネッセンス測定（TL） } \\
\text { 鉱物質の電荷トラップ }\end{array}$ & $\begin{array}{l}\text { EN1788 (1996), } \\
\text { (2001 改訂) }\end{array}$ & $\begin{array}{l}\text { ハーブ・スパイス類 }(6), \text { エビ (1), 貝類 }(0.5) \text {, } \\
\text { 生鮮 (1) 及び乾燥野菜果物 (8), バレイショ } \\
(0.05)\end{array}$ \\
\hline $\begin{array}{l}\text { (7)光励起ルミネッセンス測定（PSL） } \\
\text { 鈗物質の電荷トラップ（スクリーング） }\end{array}$ & $\begin{array}{l}\text { EN13751 (2002) } \\
\text { (2009 改訂) }\end{array}$ & ハーブ・スパイス類 $(10)$, 貝類 $(0.5)$ \\
\hline $\begin{array}{l}\text { (8) DEFT/APC } \\
\text { 直接フィルター蛍光顕微観察と好気的平板カウ } \\
\text { ントで得た微生物数の比較（スクリーニング） }\end{array}$ & EN13783 (2001) & ハーブ・スパイス類（5） \\
\hline $\begin{array}{l}\text { (9) DNA コメットアッセイ } \\
\text { DNA の損傷（スクリーニング） }\end{array}$ & EN13784 (2001) & 鶏肉 (1), 豚肉 (1), 植物細胞 (種子類) (1) \\
\hline $\begin{array}{l}\text { (10) LAL/GNB 法 } \\
\text { エンドトキシン測定とグラム陰性菌数の比較 } \\
\text { (スクリーニング) }\end{array}$ & EN14569 (2004) & 鶏肉 \\
\hline
\end{tabular}


に示されており，タマネギやニンニク，シャロット への $75 \mathrm{~Gy}$ (フランス) から香辛料やハーブ，野菜 調味料 (メンバー国)，ミルク製品に使用する䍍類 の胚芽及びフレーク，乾燥血液，血清，それらの 凝固物への $10 \mathrm{kGy}$ (ベルギー, チェコ, フランス） に及ぶ。我が国では，馬鈴薯の芽止め処理のため， 150Gy を超えない $\gamma$ 線の照射のみが認められてい る。照射食品の公的な検知法は, 厚生労働省の厚生 労働科学研究補助金により平成 17 年から 23 年にか けて国立医薬品食品衛生研究所が主体となり「放射 線照射食品の検知技術に関する研究」, 「電子スピン 共鳴法による放射線照射食品の検知法の開発に関す る研究」を実施し, 平成 19 年 7 月 6 日に食安発第 0706002 号 ${ }^{19)}$ で熱ルミネッセンス（TL）試験法を 公定試験法として検疫検査に適用する道を開いた。 しかし，ヨーロッパ標準試験法となっている TL 法 (EN1788) とは手順や判定など試験の多くの部分で 異なる内容となっており, いくつかの課題も提起さ れた ${ }^{20), 21) 。 ~}$

その後，食安発第 1213002 号（H19.12.13），食安 発第 0529004 号（H20.5.29）, 食安発第0812002 号 (H20.8.12), 食安発第 1211002 号 (H20.12.11), 食 安発第 0630002 号 (H21.6.30), 食安発第 0807 第 2 号（H21.8.7）と，試験方法や判定規準の変更及び 試験可能な食品を順次追加するために改正を重ね
た。食安発第 0330 第 3 号（H22.3.30）では新たに アルキルシクロブタノン法が追加され，最新の通知 である食安発第 0910 第 2 号 (H24.9.10) では電子 スピン共鳴法（骨及び結晶性の糖）が加わり $\mathrm{EN}$ 規 格に照らし合わすと 4 つの検知法が公定試験法と なっている ${ }^{22)}$ 。

その対象となる食品を Table 3 に示す。

\section{3 照射食品検知法と利用の実態}

放射線照射される食品類は多種にわたるが，欧州 では 2012 年に照射された食品は全体で $7972 \mathrm{t}$ であ り，その内の $91 \%$ がベルギー $(64.7 \%)$ ，オランダ $(18.5 \%) ，$ フランス $(7.7 \%)$ の三か国によって占め られている。照射された食品もカエルの足 $(36 \%)$, 家禽肉 $(35 \%)$, 乾燥アロマハーブ $(15 \%)$ の三種類 が大半を占める。重量当たりの割合なので，乾燥ア ロマハーブ類の処理容量は大きいと考えられる ${ }^{23)} 。$

2000 年以降の照射される食品の量は, Fig. 1 に示 すように当初 $20,000 t$ を超えていたが，食品表示や 照射施設のライセンスの強化，違反品の摘発が影響 して 2006 年以降落ち込み，その後はほぼ 7,000t 内 外を推移している。また，この間 EUで 1 年間に検 査される検体数は $5,000 \sim 7,000$ であり，そのうち 検査に不合格（放射線照射の表示が不適切または照 射許可品目外）となり違法判定を受けたもの及び

Table 3 我が国の放射線照射食品検知法と対象となる食品（食安発第 0910 第 2 号（H24.9.10）より抜䊀） 22)

I．アルキルシクロブタノン法

・脂肪を抽出可能な食品 (牛肉, 豚肉, 鶏肉, 鮭, カマンベールチーズ等)

II . 熱ルミネッセンス (TL) 試験法

ケイ酸塩鉱物が分離可能な食品

農産物（香辛料，野菜類，果実類及び茶等）及び水産物（あさり，えび及びしゃこ）注1)

注 1）厚生労働科学研究事業に扔いて, 黒胡椒, ウコン, オレガ, , パプリカ, 赤唐辛子, フェネグリーク, クミン, セロリシー ド, オールスパイス, 黒胡麻, コリアンダー, 生姜, カシア, パセリシード, ローレル, わさび, シナモン, ニンニク, ガジュツ, 白胡椒, アニスシード, クローブ, スターアニス, セージ, タイム, タラゴン, フェンネル, ミント, マ ジョラム, えんどう豆头, しいたけ, だいこん, ケール*, マカ*, 大麦若葉*, 白菜*, 野沢菜*, 小松菜*, シ ソ*,にら*，キャベッ*，ごぼう*，たまねぎ，ねぎ，ほうれんそう，レタス， れんこん十, りんご*, いちご*, ウーロン茶, プーアール茶, 麦茶, ドクダミ茶, あさり, えび及びしゃこ（*乾燥のみ, 十生鮮のみ) から試験に必 要な量の鉱物が得られることが確認されている。ただし, 検体の状態によっては本検知法が適用できない場合もある。

III. 電子スピン共鳴 (ESR) 法

放射線照射（以下，照射）によりラジカルを生成する食品

貝殼及び結晶性の糖を含む食品注2)

注 2）貝殼付の貝（ハマグリ及びアサリ），糖結晶を含む乾燥果実（マンゴー，パイナップル，パパイヤ）について本試験 法の適用が確認できている。 
検査で判定不能とされるもの割合は，それぞれ約 1.4〜 4\%及び $1.6 \%$ を超えない範囲を変動している (Table 4)。

使用される検査方法の適用頻度をまとめてみる と, Fig. 2のように熱ルミネッセンス法（EN1788）, 光刺激ルミネッセンス法 (EN13751), 電子スピン 共鳴法 (EN1787 : セルロース対象) や電子スピン 共鳴法（EN1786：骨を対象）を併用，或いは単独 で使用する事例が多い。これらの方法は，(1)判定の 信頼性が高い，(2)簡便で低コストで実施できる，(3) 測定が短時間でできる，(4)測定対象が広いなどの特 性のいくつかを持っており, 併用することで判定の

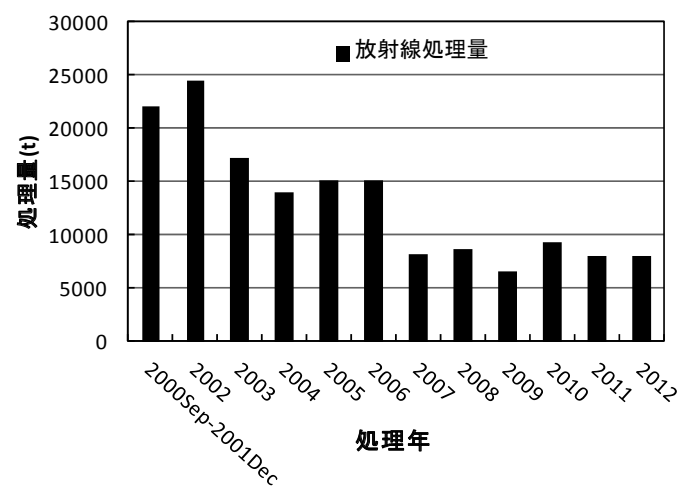

Fig. 1 EU メンバー国において年間に放射線照射 される食品の処理量の変遷
信頼性と検査の効率が高まる。

検查品目毎に用いられた放射線照射食品の検知 法と判定結果の関係（Table 5) を調べた結果，ア ロマハーブ，スパイスと野菜の調味料 (乾燥)，栄 養補助食品，ソース及びスープ（乾燥）やその 他で違法な照射食品が多く，また先述の EN1788, EN13751，EN1786，EN1787 の検査法が使用されて いるのがわかる。また，甲殼類や肉やその製品にお

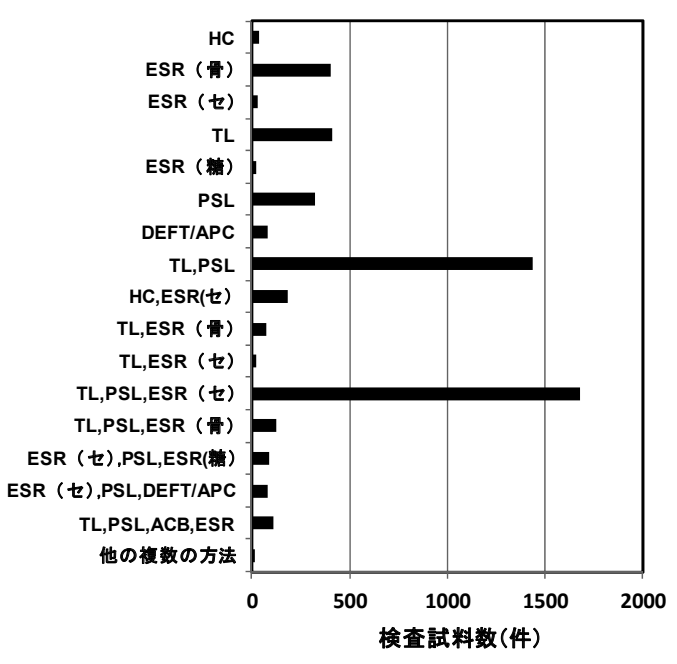

Fig. 2 EU メンバー国で放射能照射食品の検査に 用いられた方法 (2012 年) ${ }^{23)}$

Table 4 EU メンバー国で放射線照射食品の検査を行った総検体数と違法及び判定不能とされた 検体数の推移

\begin{tabular}{cccccc}
\hline 検査年 & 総検体数 & 違法判定数 & 割合 $(\%)$ & 判定不能数 & 割合 $(\%)$ \\
\hline 2000 Sep-2001Dec & 6,748 & 97 & 1.4 & - & - \\
2002 & 5,031 & 137 & 2.7 & 21 & 0.42 \\
2003 & 5,663 & 193 & 3.5 & 25 & 0.44 \\
2004 & 7,169 & 279 & 3.9 & - & - \\
2005 & 7,005 & 281 & 4.0 & 101 & 1.44 \\
2006 & 6,386 & 203 & 3.3 & 42 & 0.66 \\
2007 & 6,463 & 203 & 3.14 & 84 & 1.3 \\
2008 & 6,220 & 142 & 2.28 & 74 & 1.19 \\
2009 & 6,265 & 127 & 2.03 & 93 & 1.48 \\
2010 & 6,244 & 144 & 2.3 & 48 & 0.77 \\
2011 & 5,397 & 105 & 2.0 & 60 & 1.11 \\
2012 & 5,182 & 123 & 2.4 & 80 & 1.54 \\
\hline
\end{tabular}

*違法判定された検体には，放射線照射の表示が不適正或いは照射認可外の照射品が含まれる。 
Table 5 EU メンバー国で検査品目毎に使用した放射線照射食品検知法と判定結果の関係（2012 年）の抜粋 23)

\begin{tabular}{|c|c|c|c|c|c|c|}
\hline 検査品目 & 検査国 & 検査方法 & 検体総数 & 適法 & 判定不能 & 違法 \\
\hline \multirow{4}{*}{$\begin{array}{l}\text { アロマハーブ，スパイスと野菜の調 } \\
\text { 味料 (乾燥) }\end{array}$} & ドイツ & EN1788; EN13751; EN1787 & 1304 & 1285 & 15 & 4 \\
\hline & ルーマニア & EN1788; EN13751 & 69 & 68 & 0 & 1 \\
\hline & フィンランド & $\begin{array}{l}\text { EN1788 for confirmation; } \\
\text { EN13751 }\end{array}$ & 130 & 119 & 3 & 8 \\
\hline & 英国 & EN1788; EN13751 & 164 & 156 & 5 & 3 \\
\hline \multirow{9}{*}{ 栄養補助食品 } & ベルギー & EN1788 & 18 & 14 & 2 & 2 \\
\hline & リトアニア & EN13783 & 33 & 13 & 0 & 20 \\
\hline & フィンランド & $\begin{array}{l}\text { EN1788 for confirmation; } \\
\text { EN13751 }\end{array}$ & 48 & 35 & 0 & 13 \\
\hline & ドイツ & EN1786 & 108 & 97 & 9 & 2 \\
\hline & イタリア & $\begin{array}{l}\text { EN1788; EN1785; EN13784; } \\
\text { EN13751; EN1786 }\end{array}$ & 12 & 9 & 1 & 2 \\
\hline & ラトビア & EN1788 & 11 & 6 & 0 & 5 \\
\hline & オランダ & EN1788; EN13751 & 61 & 52 & 0 & 9 \\
\hline & ポルトガル & EN13751 & 20 & 18 & 0 & 2 \\
\hline & 英国 & EN1788; EN13751 & 30 & 26 & 3 & 1 \\
\hline \multirow[b]{2}{*}{ 特定の栄養用途のための食品 } & ポーランド & EN1788 & 3 & 1 & 0 & 2 \\
\hline & フィンランド & $\begin{array}{l}\text { EN1788 for confirmation; } \\
\text { EN13751 }\end{array}$ & 6 & 4 & 0 & 2 \\
\hline \multirow{2}{*}{$\begin{array}{l}\text { ハーブ茶及びインフュージョン（浸 } \\
\text { 出物) }\end{array}$} & ブルガリア & EN1788; EN13751; EN1787 & 10 & 8 & 0 & 2 \\
\hline & フィンランド & $\begin{array}{l}\text { EN1788 for confirmation; } \\
\text { EN13751 }\end{array}$ & 13 & 11 & 1 & 1 \\
\hline \multirow{5}{*}{$\begin{array}{l}\text { ソース及びスープ (乾燥) } \\
\text { その他 }\end{array}$} & ドイツ & EN1784; EN1786 & 84 & 83 & 0 & 1 \\
\hline & フランス & EN1788 & 8 & 4 & 1 & 3 \\
\hline & オーストリア & EN1788; EN13751 & 26 & 24 & 0 & 2 \\
\hline & 英国 & EN1788; EN13751 & 29 & 21 & 1 & 7 \\
\hline & フィンランド & $\begin{array}{l}\text { EN1788 for confirmation; } \\
\text { EN13751 }\end{array}$ & 33 & 26 & 0 & 7 \\
\hline 特別なハーブ混合物 & オランダ & EN1788; EN13751 & 59 & 57 & 0 & 2 \\
\hline \multirow{2}{*}{$\begin{array}{l}\text { 甲殼類, 貝類, ムール貝等と他の水 } \\
\text { 生動物（軟体動物等） (製品を含む) }\end{array}$} & ドイツ & EN1788; EN13751 & 86 & 83 & 1 & 2 \\
\hline & ベルギー & EN1788 & 20 & 16 & 3 & 1 \\
\hline 魚及び魚製品 & ドイツ & EN1788; EN13751; EN1786 & 124 & 121 & 0 & 3 \\
\hline \multirow{2}{*}{ カエルの足 } & ポーランド & EN1786 & 3 & 1 & 0 & 2 \\
\hline & イタリア & EN13751 & 9 & 4 & 0 & 5 \\
\hline 料理及び栔菜 (調理済み) & ドイツ & EN1788; EN13751; EN1787 & 67 & 64 & 1 & 2 \\
\hline 果実 (乾燥) & ドイツ & $\begin{array}{l}\text { EN1788; ASU § } 64 \text { LFGB } \\
\text { L12.01-1(ESR); EN13751 }\end{array}$ & 65 & 63 & 1 & 1 \\
\hline インスタント麺 & 英国 & EN1788; EN13751 & 51 & 40 & 4 & 7 \\
\hline \multirow{4}{*}{ 肉類（含む肉製品） } & ポーランド & EN1784 or EN1786 & 11 & 11 & 0 & 0 \\
\hline & ドイツ & EN1788; EN13751; EN1786 & 132 & 132 & 0 & 0 \\
\hline & オーストリア & EN1786 & 62 & 62 & 0 & 0 \\
\hline & イタリア & EN13783; EN13751; EN1787 & 67 & 67 & 0 & 0 \\
\hline チーズ，ナッツ類 & スロバキア & EN1784 or/and EN1788 & 22 & 22 & 0 & 0 \\
\hline 豆類，オイルシード, ナッツ & ドイッ & EN1784 & 15 & 15 & 0 & 0 \\
\hline
\end{tabular}


いてもこれらの方法が使用され, 脂質の放射線によ る分解生成物を検出する EN1784 は，チーズ，ナッ ツ，豆類，一部の国で肉を対象として使用されてい るに過ぎない。脂質の放射線により生成する $2-$ ア ルキルシクロブタノン類を検出する EN1785 の適用 例は少ない。このことは，分析に係る技術的な煩雑 さと労力, 人材を必要とし, 時間や費用のかかるこ とが背景にある。

一方，我が国の公定検知法は TL法，アルキル シクロブタノン法, 電子スピン共鳴法（骨及び結 晶性の糖）の 4 種類であり，それぞれ EN1788, EN1785，EN1786，EN13708 に対応するものである。 国内に打いて，公定試験法が公示されてからの輸入 食品監視指導計画に基づく監視指導結果（モニタリ ング検査の検查実施数と違法食品の件数）を編集し
たものを Table 6 に示す。年度により差異はあるが, 農産加工品食品において違反品が認められるケース が多い。違反品が検出される割合は平成 21 年度が $2.2 \%$ であた以降，最近は $1 \%$ を超えない状況にあ る。輸入時のモニタリング検査だけでなく，国内流 通品の都道府県での収去食品の検査や自主検査など で違反が認められた食品や輸入の恐れのあった食品 類を Table 7 に示す。香辛料や健康食品が大半を占 めており，輸出国では中国が多くを占めるが，バン グラディシュやブラジル，チリ，タイ，インド，ド イツの他，米国や英国なども含まれる。

以上，我が国と $\mathrm{EU}$ に打ける放射線照射食品の検 查方法とその実情を比較した。スクリーニング法 としての光刺激ルミネッセンス法 (EN13751), セ ルロースを対象とした電子スピン共鳴法（EN1787）

Table 6 輸入食品監視指導計画に基づく放射線照射食品の監視指導結果（モニタリング実施状況）

\begin{tabular}{|c|c|c|c|c|c|c|}
\hline 品目 & $\mathrm{H} 20$ & $\mathrm{H} 21$ & $\mathrm{H} 22$ & $\mathrm{H} 23$ & $\mathrm{H} 24$ & $\mathrm{H} 25^{*}$ \\
\hline $\begin{array}{l}\text { 畜産食品 } \\
\text { (牛肉, 豚肉, 鷄肉, 馬肉, その他食鳥肉等) }\end{array}$ & - & - & $0 / 14$ & $0 / 16$ & $0 / 31$ & $0 / 23$ \\
\hline $\begin{array}{l}\text { 畜産加工食品（ナチュラルチーズ，食肉製品，アイスク } \\
\text { リーム, 冷凍食品 (肉類) 等) }\end{array}$ & - & - & - & - & - & - \\
\hline $\begin{array}{l}\text { 水産食品 } \\
\text { (二枚具，魚類，甲殼類（エビ，カニ)) }\end{array}$ & - & - & $0 / 7$ & $0 / 8$ & $0 / 27$ & $0 / 20$ \\
\hline $\begin{array}{l}\text { 水産加工食品 } \\
\text { (魚類加工品, 冷凍食品, 魚介類卵加工品等) }\end{array}$ & - & $2 / 5$ & $0 / 3$ & $0 / 6$ & $0 / 9$ & $0 / 3$ \\
\hline $\begin{array}{l}\text { 農産食品 (野菜, 果実, 麦類, とうもろこし, 豆類, 落 } \\
\text { 花生, ナッツ類, 種実類等) }\end{array}$ & $0 / 6$ & $0 / 26$ & $0 / 19$ & $0 / 17$ & $0 / 142$ & $0 / 94$ \\
\hline $\begin{array}{l}\text { 農産加工食品 } \\
\text { (冷凍食品, 野菜·果実加工品, 香辛料, 即席めん類等) }\end{array}$ & $8 / 420$ & $4 / 239$ & $3 / 235$ & $1 / 344$ & $1 / 406$ & $0 / 240$ \\
\hline $\begin{array}{l}\text { その他の食料品（健康食品，スープ類，調味料，菓子類, } \\
\text { 食用油脂, 冷凍食品等) }\end{array}$ & $0 / 7$ & $0 / 1$ & $0 / 3$ & $0 / 2$ & $0 / 2$ & 0 \\
\hline 検査検体数 & 433 & 271 & 281 & 393 & 617 & 380 \\
\hline
\end{tabular}

\footnotetext{
${ }^{*} \mathrm{H} 25$ 年度は中間検査状況

**表中分子は，違反食品件数，分母は検査検体数を示す。

(出典 : http://www.mhlw.go.jp/topics/yunyu/kanshi/index.html)
}

Table 7 輸入時モニタリング検査，国内流通品の検査で放射線照射による違反とされた食品及び海外情報 に基づき検査が強化された食品（平成 19 年 7 月以降）

\footnotetext{
大麦若葉粉末, 乾燥コリアンダー, 乾燥クミン, 乾燥ミント, 乾燥大根葉, 乾燥ペパーミント, 乾燥唐辛子, 乾燥 シイタケ, ウーロン茶, 乾燥ネギ, 黒胡椒, 乾燥ケール粉末, 茶, ガラムマサラ, マカ, パプリカ, 冷凍ボイルシャ コ,イギリス産ビスケット, 発酵抽出物（イソフラボン）
} 
を他の方法と併用することで効果的な試験を実施し ている。国内でも, 厚生労働科学研究費補助金によ り「セルロースを含む食品への電子スピン共鳴法 の適用」などの研究が平成 $20 \sim 21$ 年, 23 年 ${ }^{24) ~ 26) ~}$ と実施され，検知法として一定の有効性が認められ ていたが，公定試験法として取り上げられなかった のは残念である。

\section{3 照射食品検知法の開発と今後の展望}

放射線照射食品を試験するための公定試験法は, 測定限界や誤判定に繋がる要因を検証するため, 国 際的なコラボ試験などを通して測定者や装置の種 類, 試験環境による判定への影響を把握した上で, 測定に関わる作業や判定, 校正など標準化のための 方法を規格化し作成される。そして, 対象食品の範 囲や判定の確実性に関するファクターを理解した上 で適用することになる。食品や食品原料などは非常 に多岐にわたり，放射線照射により食品中に生じる 物理的, 化学的, 生化学的, 生物学的变化が放射線 照射で必ずしも特異的に生じるものでない場合に は, 判定の閾值の設定ができるものかどうかの検討 も必要であるし，本来的に変化が小さく，また照射 後の環境や処理により検出限界以下となる場合に は, 一つの方法で判定できないことがある。検知法 は, 現在 EN 規格の 10 種類の標準試験法が制定さ れる以前より, 他にもいくつかの方法が検討されて いた。その中には有望とされた方法もあり,一方で, その当時の分析技術や分析機器では検知法として十 分な能力を示し得なかったものも含まれている。さ らに, 現在使用されている標準試験法についても, いくつかの短所（前処理が煩雑で高コスト, 検査に 長時間を要する, オンサイトでの実施が困難など） を持つが故に, 改善への試みが多数行われている。

この間に研究されてきた照射食品検知法について は, 数々のレビューや成書として発表されており, 開発期から実用化への経緯，そして技術の蓄積や装 置の刷新に伴う新たな試験方法の開発の流れを理解 する上で役立つ ${ }^{27) ~}$ 37)。

\section{1 照射食品検知法の開発と課題}

企業の自主検査では，通常の食品の分析をしてい る機器, 手法を応用でき, 経済性に優れたもの, 或 いは新たな品質管理に有用なものがルーチンの試
験の中で採用されるであろう。その意味では, 生 物学的方法である DEFT/APC 法 (EN13751) や LAL/GNB 法（EN14569）などは日常の食品衛生管 理に打ける微生物測定の延長でできる方法であり, 技術，コスト，分析時間と言った点でも同等な負担 の範囲にある。通常の管理基準の微生物数に比べ異 常に少ないデータが得られた場合は，何らかの殺菌 処理が行われたと推定し照射の可能性を疑うという 事例が多かった。上記の標準試験法は，基本的に好 気性微生物やグラム陰性菌の生菌数之 (生菌十死菌) を代表する指標の比を求め基準化することにより判 定の規格化を行って打り, 客観的に殺菌処理の可能 性を示し, (生菌十死菌) と言う指標は, 製造工程 での衛生的管理状況を推定する上で役立つ。

同様に，アルキルシクロブタノン（ACB）法につ いても, 食品中の残留農薬などの化学分析を行って いる企業にとっては，それほど負担なく自社内で実 施できるという点で対応しやすいものと思われる。

現在，公定試験法にはなっていないが過去から研 究されてきた方法や現在も開発中の方法と, 対象食 品の例を Table 8 に示す。

この表には記載していないが, 他にも化学発光法, ミトコンドリアDNAの測定などがある。

化学発光法は, 照射で生じた食品中の過酸化水素 や有機過酸化物をルミノール試薬と反応させ, 生じ る発光を測定するもので, 迅速・簡便, 低コス卜 という特徴を持つため, ドイッでは標準試験法と して一部の香辛料を対象に使用されていたが，加 熱処理など他の処理によっても過酸化物などが生 成し，水分や既存の過酸化物による影響を受け再 現性に課題があった。また, DNA コメットアッセ イ（EN13784:2001）は標準試験法となっているが, DNAの放射線による分解から照射の有無を調べる 方法として, 細胞内のミトコンドリア DNA の切断 による変化（DNAのスーパーコイルが環状 DNA や直鎖 DNAへ) を電気泳動で調べる方法が提案さ れた。細胞内の酵素による影響を受けないという利 点はあったが, DNAの抽出が煩雑で時間のかかる ことから，現在では使用されていない。

ガス分析は，ヘッドスペース法によるガスクロマ トグラフィにより, 水素や一酸化炭素の検出やガス センサー（複数を含む）を検出器に利用する方法が 研究された ${ }^{38) \sim 40)}$ 。また, 主に蛋白質の分解により 
Table 8 照射食品の標準試験法ではないが，過去に研究された方法及び現在も検証中の方法の例

\begin{tabular}{|c|c|c|c|}
\hline 方法 & 原理及び特徵 & 対象食品 & 参考文献 \\
\hline $\begin{array}{l}\text { ガス分析（ガスクロ又 } \\
\text { はガスセンサー） }\end{array}$ & $\begin{array}{l}\text { 照射により生成する分解ガス類を検出 } \\
\text { ·簡便，迅速，低コスト } \\
\text { ·微生物污染による疑陽性に注意 }\end{array}$ & $\begin{array}{l}\text { 凍結肉及び家禽肉 (CO) } \\
\text { 胡椒 (H2) } \\
\text { 凍結エビ, 卵殼, 凍結鶏肉 (H2) }\end{array}$ & $\begin{array}{l}\text { Furuta }(1992)^{38)} \\
\text { Dohmaru }(1989)^{39)} \\
\text { Hitchzcock }(2000)^{40)}\end{array}$ \\
\hline $\begin{array}{l}\text { パルス炎光光度検出器 } \\
\text { (PFP) による分析 }\end{array}$ & $\begin{array}{l}\text { 分解生成物 (有機硫黄化合物) の検出 } \\
\text { ·高感度, 選択 } \mathrm{t} \text { 的, 再現性のある方法 }\end{array}$ & $\begin{array}{l}\text { 肉類 } \\
\text { 七面鳥胸肉 }\end{array}$ & $\begin{array}{l}\text { Amirav }(1995)^{41)} \\
\text { Fan }(2002)^{42)}\end{array}$ \\
\hline $\begin{array}{l}\text { E-Nose 分析 (高速ガ } \\
\text { スクロと半導体検出シ } \\
\text { ステム) 及びパターン } \\
\text { 認識システムの利用 }\end{array}$ & $\begin{array}{l}\text { 照射により生じる揮発性化合物を高速で分 } \\
\text { 離し，複数の半導体 (SAW) センサーで検 } \\
\text { 出しその応答をパターン化して判別 } \\
\text { ·揮発性化合物プロファイル分析 } \\
\text { ·高感度, 簡便, 低コスト, 迅速 }\end{array}$ & $\begin{array}{l}\text { トマト, } \\
\text { アンチョビソース } \\
\text { 粉末赤唐辛子 } \\
\text { 豚ひき肉 } \\
\text { エリンギ (主成分分析導入) } \\
\text { パプリカ, 黒胡椒, 赤唐辛子, } \\
\text { シナモン }\end{array}$ & $\begin{array}{l}\text { Winquist }(1995)^{43)} \\
\text { Kim et al. }(2004)^{44)} \\
\text { Lee et al. }(2005)^{45)} \\
\text { Kim et al. }(2008)^{46)} \\
\text { Akram et al. }(2012)^{47)} \\
\text { Ahn }(2013)^{48)}\end{array}$ \\
\hline o-チロシン法 & $\begin{array}{l}\text { 肉類等の蛋白質中の芳香族アミノ酸がヒド } \\
\text { ロキシラジカルと反応して生成する } 0 \text { - チロ } \\
\text { シンを分析する } \\
\text { ·非照射品にも存在する }\end{array}$ & $\begin{array}{l}\text { 肉類及び甲殼類 } \\
\text { 鶏肉 } \\
\text { 冷凍エビ } \\
\text { 骨付き鶏肉 }\end{array}$ & $\begin{array}{l}\text { Karam }(1988)^{49)} \\
\text { Meier }(1990)^{50)} \\
\text { 及川 }(2001)^{51)} \\
\text { Miyahara }(2002)^{52)}\end{array}$ \\
\hline インピーダンス法 & $\begin{array}{l}\text { 細胞膜やそのイオン透過性の変化を電気イ } \\
\text { ンピーダンスとして測定 } \\
\text { ·簡便, 迅速, 低コスト } \\
\end{array}$ & ジャガイモ & Hayashi $(1983)^{53)}$ \\
\hline 粘度法 & $\begin{array}{l}\text { 澱粉質が放射線で分解し溶解状態での粘度 } \\
\text { が低下する性質を利用 } \\
\text { ·簡便，迅速，低コスト } \\
\text { ·熱処理は影響を与える } \\
\text { ·ESR 又は TL 法で再検証が必要 }\end{array}$ & $\begin{array}{l}\text { 香辛料 } \\
\text { 胡椒 (pH13.8で識別良好) } \\
\text { 米 (迅速分析法) }\end{array}$ & $\begin{array}{l}\text { Glidewell }(1993)^{54)} \\
\text { Hayashi }(1996)^{55)} \\
\text { Shufang }(2013)^{56)}\end{array}$ \\
\hline 胚培養法 & $\begin{array}{l}\text { ·種子などの発根, 発芽が放射線照射によ } \\
\text { り抑制される性質を利用 } \\
\text { ·簡便，迅速，低コスト，特殊な機器を要 } \\
\text { しない, 低線量照射の検出が可能 }\end{array}$ & $\begin{array}{l}\text { 相橘類, リンゴ, 米, 麦, } \\
\text { 玉䓤, シャロット } \\
\text { スイカ, メロン, パパイア } \\
\text { 麦, 大豆, ひよこ豆, 黒目豆 }\end{array}$ & $\begin{array}{l}\text { Kawamura }(1996)^{57)} \\
\text { Selvan }(1999)^{58)} \\
\text { Marín-Huachaca }(2004)^{59)} \\
\text { Khawar }(2010)^{60)}\end{array}$ \\
\hline $\begin{array}{l}\text { 蛋白質の免疫学的検出 } \\
\text { (免疫ブロット法) }\end{array}$ & $\begin{array}{l}\text { 抗体と卵白蛋白の免疫反応の減少を評価 } \\
\text { ·簡便，迅速，低コスト，高選択性 }\end{array}$ & 鶏卵 & Kume $(1994)^{61)}$ \\
\hline $\begin{array}{l}\text { 修飾 DNA 塩基の免疫 } \\
\text { 学的検出 (ELISA 法) }\end{array}$ & $\begin{array}{l}\text { 照射されたDNA が水分子との反応等で生 } \\
\text { 成する修飾された核酸塩基を抗体で検出 } \\
\text { ·簡便, 迅速，高選択性 } \\
\text { ·微量分析で沉用性の高い技術 } \\
\text { ·抗体試薬の入手とその安定性に注意 }\end{array}$ & $\begin{array}{l}\text { エビ (ジヒドロチミジン) } \\
\text { 動物, 細菌 (8-ヒドロキシ -2- } \\
\text { デオキグアノシン) } \\
\text { 特肉, 豚肉, 鷄肉 (同上) }\end{array}$ & $\begin{array}{l}\text { Tyreman }(1998)^{62)} \\
\text { Alam }(2006)^{63)} \\
\text { Kikuchi }(2007)^{64)}\end{array}$ \\
\hline $\begin{array}{l}\text { アルキルシクロブタノ } \\
\text { ン類の免疫学的検出 } \\
\text { (ELISA 法) }\end{array}$ & $\begin{array}{l}\cdot \text { ·高感度, 高選択性, 低コスト } \\
\text { ·高い作業能力, 微量分析 } \\
\text { ·抗体試薬の入手とその安定性に注意 }\end{array}$ & $\begin{array}{l}\text { 鷄肉 }(2-\mathrm{ACB}) \\
\text { 牛挽肉 }(2-\mathrm{DCB})\end{array}$ & $\begin{array}{l}\text { Elliott }(1995)^{65)} \\
\text { Zhao }(2013)^{66)}\end{array}$ \\
\hline $\begin{array}{l}\text { 赤外分光法 } \\
\text { FT-IR, FT-Raman } \\
\text { 及び } \\
\text { 2D-IR 分光法 }\end{array}$ & $\begin{array}{l}\text { 多波長同時分析 } \\
\text { (放射線照射による影響を受ける波長領域 } \\
\text { の選択を多数選択しその変化を統計解析を } \\
\text { 実施) } \\
\text { ·多成分系での解析に有効 (2D-IR) }\end{array}$ & $\begin{array}{l}\text { 澱粉（トウモロコシ，麦，馬鈴 } \\
\text { 薯等) } \\
\text { 米 } \\
\text { 牛肉 } \\
\text { スピルリナ (2D-IR 分光法) } \\
\text { 粉ミルク }\end{array}$ & $\begin{array}{l}\text { Kizil }(2002)^{67)} \\
\text { Shao }(2011)^{68)} \\
\text { Badr }(2012)^{69)} \\
\text { Liu }(2013)^{70)} \\
\text { Kong }(2013)^{71)}\end{array}$ \\
\hline $\begin{array}{l}{ }^{1} \mathrm{H}-\mathrm{NMR} \text { 分光法 } \\
\text { (2D DOSY 法) }\end{array}$ & $\begin{array}{l}\text { 照射による脂質のトリグリセライド中の不 } \\
\text { 飽和及び飽和脂肪酸量の比や脂質の減少等 } \\
\text { を検出 } \\
\text { ·多成分系での解析に有効 (2D DOSY) }\end{array}$ & $\begin{array}{l}\text { 肉類 } \\
\text { 大豆 } \\
\text { セサミシード }\end{array}$ & $\begin{array}{l}\text { Stefanova }(2011)^{72)} \\
\text { Zoumpoulakis }(2012)^{73)} \\
\text { Ribeiroa }(2014)^{74)}\end{array}$ \\
\hline
\end{tabular}


生成した照射臭の原因となる有機硫黄化合物 (ジメ チルスルフィド，ジメチルジスルフィドなど）を，パ ルス型炎光光度検出器 (PFP) を組み合せたガスク ロマトグラフで検出するシステムも検討された ${ }^{41), 42) 。 ~}$ 現在では，食品の品質管理にも使用される揮発性物 質をより高感度，迅速性，経済的に分析できる高速 ガスクロマトグラムに複数の特殊なセンサ, 相関解 析ソフトを組み合わせた E-Nose による研究がいく つか報告されて抢り，新たなスクリーニング法とし て注目される ${ }^{43) \sim 48) 。 ~}$

また，蛋白質が照射された場合に生じる o-チロ シンについても, 照射で特異的に生じる物質として 一時盛んに研究されたが, 未照射の食品にも存在す ることが確認された後は研究が減少した $\left.{ }^{49) ~} 52\right)$ 。

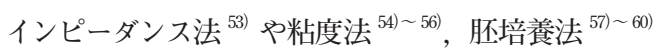
については，保存環境や熱処理の有無などによる影 響を受ける可能性と再現性に課題はあるが，低線量 の評価ができ，簡便かつ特殊な機器を要しないの で, 限定した対象食品に対し適正な試験手順で実施 するならば，企業の自主検查として有用性がある。

また, 従来から免疫反応の特異性を利用し照射し た食品中に生成するマーカー物質を検知する方法は 色々と検討されてきた。従来, 食品メーカーではア レルゲンとなる蛋白質の検出に免疫学的な試験法を 使用してきており，企業自ら検知法として特許を取 得している例もある。食品に特殊な蛋白質が放射線 照射により変質し免疫反応が低下するという性質を 免疫ブロット法などで放射線照射の検知に利用する 方法も研究されてきた ${ }^{61)}$

その他, DNA の塩基の酸化或いは $\mathrm{OH}$ ラジカル との反応で生成した化合物 ${ }^{62) ~}{ }^{64)}$ や, 脂質の脂肪酸 から生じる 2-アルキルシクロブタノン類を ELISA

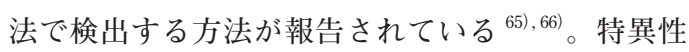
を持ち, 高感度で簡便, 低コスト, 迅速に分析がで きることから, 前処理条件や測定精度, 安定性の 検討を進め対象品目の拡大が望まれる。2-アルキル シクロブタノン類の検知に関しては，公定試験法 （EN1785）との比較研究により実用化の方向性が見 出されれば有用である。

最近再び研究が進められているものとして, 赤外 分光測定 ${ }^{67) ~ 71)}$ p ${ }^{1} \mathrm{H}-\mathrm{NMR}$ 分光法 ${ }^{72) ~ 74)}$ がある。測 定機器の性能の向上と新しい解析ソフトの開発に より，多様な食品の照射履歴を検知できる可能性
がある。2D-IR 分光法や ${ }^{1} \mathrm{H}-\mathrm{NMR}$ 分光法 (Diffusion Ordered Spectroscopy:2D-DOSY 法）はまだ研究の 緒についたばかりであり，またその測定原理も複雑 である。しかし，多成分物系の評価に有効とされ， 照射食品の検知に優れ，一般的な使用ができるなら ば，現在多用される TL 法や PSL 法，ESR 法で判定 できない事例への適用が期待される。

\section{2 照射食品検知法の実用上の制約と改良へむけて の研究}

当センターで現在対応している試験は, TL 法, PSL 法，ESR 法である。輸入食品に関して違反品 の多くは，香辛料，八ーブ，食品原料，健康食品で あり，その種類，形状，性質は非常に多様で， EN の標準試験方法や，国内の厚生労働省の通知法が規 定する前処理法では適正な判定ができない，或いは 検出感度が低下し, 䛊判定を生じる可能性がある。 また, 検知法の適用範囲を拡大する意味に打いても, 今までに分析経験のない食品試料の分析は，より良 い方法を模索していく上で重要である。

TL 法や PSL 法は確立した方法であるが，食品の 成分の特異的な变化を測定しているものでないこと に留意する必要がある。農産品など生産時に付着 し，また加工過程で環境から污染したダストに含ま れる鉱物質に生じた電荷トラップを, 熱或いは近赤 外光による刺激により発光として計測している。こ れらの照射による痕跡は，時間と共に，またその 後の加熱処理や光による曝露によって消失してい く。一方で, 平滑な表面を持ち鉱物質が付着しにく い食品や，洗浄やカット処理により污れを除去した もの，抽出やろ過，遠心分離などによる精製処理や 異物除去処理を受けたもの，鉱物質が食品成分に コート或いは吸着され有機物との分離が難しいもの では，測定に有効な鉱物質が極端に少なくなり，実 用的な試料量での分析が困難となる。このような場 合, 前処理法を工夫し, 検出原理の異なる方法を併 用することにより活路が見いだせる場合がある。

例えば，魚を原料とする粉末状の乾燥調味料など では，鉱物質が非常に少なく，TL測定時に塩酸還 流処理による蛋白質の加水分解処理を行っても充分 に分解されない。このままTL測定を行うと，未分 解の蛋白質と骨成分の混入により，未照射にもかか わらず $150 \sim 250^{\circ} \mathrm{C}$ の温度範囲に発光ピークを認め 
る場合がある (偽陽性)。そのため, 塩酸還流処理 後に比重液分離することによって微量の鉱物が回収 できる $(\text { 国内通知法 })^{75)}$ 。しかし，この処理は高温 での処理のため TL 強度の低下も生じる。その代替 えとしては, 高濃度のアルカリ溶液で蛋白質を溶融 して除去する方法が有望である ${ }^{76)}$ 。肉骨粉の識別 法 ${ }^{77)}$ や BSE 異常プリオンの不活化処理 ${ }^{78)}$ に使用 されるアルカリ処理にも似たものである。筆者も, 骨と蛋白質が混合した粉末状の試料を $2.3 \mathrm{Mol} / \mathrm{L}$ の 水酸化ナトリウム溶液で振とう処理 $\left(70^{\circ} \mathrm{C}, 30\right.$ 分間 $)$ することで, 酸加水分解より良好に鉱物を回収でき ること，またメッシュろ過の残椬（骨成分が多い） を回収し, ESR 測定も可能であることを確認して いる。

貝類の照射履歴については, 剥き身の場合, 貝の 腸管や貝全体から鉱物質を切開や洗浄などの方法に より鉱物質を回収して TL 測定するのが確実である が，貝殼で判別できれば選択肢が広がる。貝殼の場 合，粉砕試料を直接 TL 測定することでも一部の種 類は判定可能であるが，貝殼内部に取り込まれた微 量の鉱物質を高濃度の塩酸で溶かして回収し測定し た報告があり，有用な情報である ${ }^{79)}$

ESR 法を併用することにより，照射履歴の判別 に多くの情報が得られる事例として, 健康食品に使 用される食品添加物の有機酸カルシウム塩 ${ }^{80)}$ と複 数の成分からなるグルコサミン錠剤 ${ }^{81}$ がある。

有機酸カルシウムは, 天然の炭酸カルシウムに発 酵法で製造した有機酸を反応させて合成する。鉱山 から産出される天然炭酸カルシウムには, 歴史年 代が非常に古く自然放射線を長期間曝露されたも のがある。その中に含まれる鉱物質は, PSL法で積 算発光量の閾值 (5,000 カウント) を超え, TL 法で glow1 の発光ピーク温度が $250^{\circ} \mathrm{C}$ 近辺という照射品 のような結果を与える。このような炭酸カルシウム から合成される種々の有機酸カルシウム塩も, 製造 の過程で自然放射線が曝露した特殊な鉱物質を受け 取り，自らもTL法や PSL法で照射されたものと判 定される。このような場合, PSL 法では, $1 \mathrm{kGy} の$ 放射線を再照射し, 校正 PSLを測定してスクリー ニング PSL/校正 PSL の比を取ることによって未照 射の可能性を判定できるが, TL 法では, TL 比が 0.1 以下であっても製品に照射品が混合していると判定 される。炭酸カルシウムと一部の有機酸カルシウム
については，照射品の ESR 測定が可能であり，そ のシグナルが安定であるので，TL 法や PSL 法で判 定の難しいケースでも適正な評価が可能になる。ま た，TL法や PSL 法で評価できない有機酸も，結晶 性であるものは比較的安定に ESR 測定が可能であ る。グルコサミン錠剤の場合は，錠剤を構成する成 分は, グルコサミン塩酸塩やセルロース (結晶性), そして酸化ケイ素や微量のヒアルロン酸などであ る。

錠剤から回収できる鉱物質は，メーカーにより大 きく異なり，原料の異物管理ができているものでは 鉱物質が少なく，TL法及び PSL 法での分析が難し い。ESR 法によりグルコサミン塩酸塩 $(50 \%$ w/w 程度含むもの）を測定した場合，純正試薬と比較し ても，照射されて生じるラジカルの ESR シグナル は類似しており，ほぼ同等の $\mathrm{g}$ 值を与える。

また，照射後 2 週間程度の間にスペクトルの波形 に変化を生じるが，このことは照射後の経過時間を 推定する指標にもなる。

スペクトルも，純正試薬とほぼ同等のスペクトル を与えることから，未照射品との判別は容易であ る。さらにまた，賦形剤として使用されるセルロー スも, 結晶性が高く吸湿性が少ないものは, 少なく とも一ヶ月以上照射に特徴的なシグナルが観察され た。

このように，TL法，PSL法に ESR 法を併用する ことで, より多くの情報を得られる。公定試験法で ESR 法の対象となっている食品は, 現状ではまだ 限られた品目であるが，健康食品の原料や添加物な どの中には，照射後安定した特徵あるラジカルを生 成するものがあり，これらの情報を集積し利用する ことは有益である。

また, 複雑な前処理を必要とする2-アルキルシ クロブタノン類 (2-ACB 類) の検知を行っている機 関においては，標準試験法と同等の能力を持つ簡便 な手法をインハウスメソッドしての利用するケース も今後増加するであろう ${ }^{82)}$ 。 EN1785 (2003) が制 定されて以降，測定機器の進歩と $2-\mathrm{ACB}$ 類の抽出 方法の研究には目を見張るものがある。2-ACB 類の 検出能力を落とさず，前処理を簡便化し労力と資源 を節約するため, 多くの研究が進められており, 直 接溶媒抽出法や SPME（固相マイク口抽出）法を用 いた研究はメリットが大きい ${ }^{83) ~ ~ 87) 。 ~}$ 


\section{4. まとめ}

照射食品の検知試験の実務では, 食品・原料に対 応した試験法と前処理法の選択，また当該試験法に おける検出限度に近い結果に基づく判定などへの対 応が大きな課題である。このような場合, 食品試料 に基づいて適正な試験方法とその手順，また様々な 加工処理を受けた場合の影響を含め，注意点がデー ターベース化されていることが望ましい。特に過去 の経験から照射されている可能性が高く，判別の難 しい品目についてはその情報は重要である。

企業に打ける自主検査に打いては，検疫検査に用 いられるような標準試験方法のその手順に必ずしも 制約されるのではなく，真の結果に近づくための試 みを合わせて行うことにより, 今まで分析実績のな い食品や標準試験法でボーダラインにあるような判 定結果を示す事例に対して, 有用な情報を提起しう るし，改善への動力となると考える。EN の公定試 験法が確立してからすでに 10 年を過ぎ，測定機器 の改良や新しい分析機器, 分析ソフトの出現により, 照射食品の検知法も徐々に変わりつつあるといえる であろう。

\section{参考文献}

1）宮原 誠. 講座 放射線滅菌技術 12 10. 世界に おける放射線殺滅技術の展開と現状-欧米の食 品照射の動向と最近の事情及び検知法の現状-. 防菌防徽. 30(4), p.233-248 (2002).

2 ) Jana Sádecká. Irradiation of spices a - review. Czech J. Food Soc.. 25(5), p.231-242 (2007).

3 ) 小林泰彦, 菊地正博. 食品照射 : 放射線による 食品や農作物の殺菌・殺虫, 芽止め技術. 放射 線化学. 88, p.18-27 (2009).

4 ) 古田雅一. 最近の食品照射の国際動向一欧州食 品安全機関（EFSA）の見解を中心に-. 食品照 射. 46, p.27-31 (2011).

5 ) József Farkas; Csilla Mohácsi-Farkas. Review History and future of food irradiation. Trend in Food Science\&Technology. 22, p.121-126 (2011).

6 ) 久米民和. アジアに打ける食品照射の最近動 向. 食品照射. 47 (1), p.29-36 (2012).

7 ) 等々力節子. RCA 食品照射プロジェクトと各 国の照射食品の現状 (2013 年前半)。食品照射.
48 (1), p.47-65 (2013).

8 ) Kume T.; Todoriki S.. Food irradiation in Asia, the European Union, and the United States: A Status Update, Radioisotopes. 62(5), p.35-43 (2013).

9 ) Arvanitoyannis S. Ioannis. "Irradiation of food commodities techniques, Application, Detection, Safety and Consumer Opinion.” 1st Ed. London, Academic Press an imprint of Elsevier, 736p. (2010).

10）平成 26 年度輸入食品監視指導計画. 厚生労働 省.

http://www.mhlw.go.jp/topics/yunyu/kanshi/ h26/shidoukeikaku.html

11）輸入加工食品の自主管理に関する指針（ガイド ライン)，厚生労働省。

http://www.mhlw.go.jp/topics/yunyu/tp01301aj.html

12）武田 寿. 輸入食品の監視指導の実施に係る基 本的考え方について. Yakugaku Zassi I, 131 (7)， p.1003-1012 (2011).

13）第十六改正日本薬局方参考情報 最終滅菌法及 び滅菌指標体. p.2036-2037 (平成 23 年 3 月 24 日 厚生労働省告示第 65 号)，第十六改正日本 薬局方名称データベース.

http://jpdb.nihs.go.jp/jp16/

14）第十六改正日本薬局方第二追補参考情報 改正 事項 滅菌法及び滅菌指標体. p.175-179 (平成 26 年 2 月 28 日 厚生労働省告示第 47 号)。(独) 医薬品医療機器総合機構.

http://www.pmda.go.jp/kyokuhou/pdf/jpdata/ yakkyokuhou16-2.pdf

15) The analytical methods for the detection of irradiated foods are standardised by the european committee for standardization. CEN.

http://ec.europa.eu/food/food/biosafety/irradiation/anal_methods_en.htm

16）等々力節子. 食品照射の海外の動向. 食品照射. 41, p.53-53 (2006).

17) Directive $1999 / 3 /$ EC of the European parliament and of the council of 22 february 1999 on the establishment of a community list of foods and food ingredients treated with ionising radiation. 
Official Journal of the European Communities. http://eur-lex.europa.eu/legal-content/EN/ TXT/PDF/?uri=CELEX:31999L0003\&from=EN

18) List of member states' authorisations of food and food ingredients which may be treated with ionising radiation. Official Journal of the European Union.

http://eur-lex.europa.eu/LexUriServ/LexUriServ.do?uri=OJ:C:2009:283:0005:0005:EN: PDF

19）食安発第 0706002 （平成 19 年 7 月 6 日）放射 線照射された食品の検知法について，厚生労働 省.

www.mhlw.go.jp/topics/yunyu/hassyutu/ dl/263.pdf

20）関口正之ほか. 熱ルミネッセンス法による照射 食品の検知 TL 発光曲線の積分温度範囲と TL 比の関係. 食品照射. 42, p.14-23（2007）.

21）等々力節子ほか. 熱ルミネッセンス法における TL 発光曲線の積分温度範囲の TL 比に対する 影響 厚生労働省通知法と CEN 標準分析法の 比較. 食品照射. 43, p.25-36（2008）.

22）食安発 0910 第 2 号（平成 24 年 9 月 10 日）放 射線照射された食品の検知法について。厚生労 働省.

www.mhlw.go.jp/topics/yunyu/other/2012/ dl/120910-02.pdf

23) Report from the commission to the european parliament and the council on food ingredients treated with ionising radiation for the year 2012, European Commission.

http://eur-lex.europa.eu/legal-content/EN/ TXT/PDF/?uri=CELEX:52014DC0052

24）放射線照射したセルロースを含む食品への電子 スピン共鳴法の適用. 厚生労働科学研究成果 データベース.

https://mhlw-grants.niph.go.jp/niph/search/ NIDD00.do?resrchNum=201131040A 201131040A0004.pdf

25）放射線照射食品の ESR 等検知法の試験に関す る研究報告書一セルロースを含む食品（生イチ ゴ, ピスタチオ, フェネグリーク)-. 厚生労働 科学研究成果データベース. https://mhlw-grants.niph.go.jp/niph/search/ NIDD00.do?resrchNum=200939023A

200939023A0004.pdf p.72-94

26）放射線照射食品の ESR 検知法（セルロース） の試験に関する研究. 厚生労働科学研究成果 データベース。

https://mhlw-grants.niph.go.jp/niph/search/ NIDD00.do?resrchNum=200837042A

200837042A0011.pdf 200837042A0013.pdf p.215-251

27）林 徹. 検知法 (DETECTION METOD) : 食 品が適切に照射されたものか知るための検定 方法.ニューフードインダストリー. 28(12)， p.11-16 (1986).

28）内山貞夫. 総説照射食品の検知法に関する国際 的動向. Radioisotopes. 40, p.302-311 (1991).

29) Analytical detection methods for irradiated foods. A review of the current literature. Joint FAO/IAEA Division of Nuclear Techniques in Food and Agriculture IAEA, Vienna, IAEATECDOC-587 (1991).

30) Belliardo J.J.. Methods for the detection of foodstuffs treated by irradiation. Radiat. Phys. Chem. 42(1-3), p.377-382 (1993).

31) Analytical methods for post-irradiation dosimetry of foods (Technical report). Pure \& Appl. Chem.. 65(1), p.165-172 (1993).

32）河村葉子. 照射食品検知法の現状. 放射線と産 業. 69, p.29-33 (1996).

33) Yang Jae-Seung. General survey of detection methods for irradiated foods. J. the Korean $\mathrm{Nu}$ clear Soci.. 29(6), p.500-507 (1997).

34) Delincée Henry. Analytical methods to identify irradiated food. Radiat. Phys. Chem. 63(3-6), p.455-458 (2002).

35）宮原 誠. 放射線照射された食品の検知法につ いて. 保物セミナー 2008 要旨集, p.29-40 (2008). http://anshin-kagaku.news.coocan.jp/seminar 2008miyahara-1-2-2-1.pdf

36) Chauhan S. K. et al. Detection methods for irradiated foods. Food Sci. Food Safety. 8, p.4-16 (2009).

37) Akram K. et al. "Chapter 1 Analytical methods 
for the identification of irradiated foods, ionizing radiation applications, sources and biological effects.” Eduard Belotserkovsky and Ziven Ostaltsov eds, Nova Science Publishers Inc, p.1-36 (2012).

38) Furuta M. et al. Detection of irradiated frozen meat and poultry using carbon monoxide gas as a probe. J. Agric.Food Chem.. 40, p.1099-1100 (1992).

39) Dohmaru T. et al. Identification of irradiated pepper with the level of hydrogen gas as a probe. Radiat. Res. 120, p.552-555 (1989).

40) Hitchcock Christopher H. S. Determination of hydrogen as a marker in irradiated frozen food. J. the Sci. Food Agric.. 80, p.131-136 (2000).

41) Amirav A.; Jing H.. Pulsed flame photometer detector for gas chromatography. Anal. Chem.. 67, p.3305-3318 (1995).

42) Fan X. et al. Volatile sulfur compounds in irradiated precooked turkey breast analyzed with pulsed flame photometric detection. J. Agric. Food Chem.. 50, p.4257-4261 (2002).

43) Winquist F. et al. Screening of irradiated tomatoes by means of an electronic nose. Proceedings of the transducers ' 95 , Eurosensors IX, the 8th International conference on solid-state sensors and actuators, and eurosensors IX. Stockholm, Sweden (June 25-29), p.691-699 (1995).

44) Kim Jae H. et al. Color, flavor, and sensory characteristics of gamma-irradiated salted and fermented anchovy sauce. Radiat.Phys.Chem.. 69, p.179-187 (2004).

45) Lee Jeung H. et al. Effect of gamma-irradiated red pepper powder on the chemical and volatile characteristics of kakdugi, a korean traditional fermented radish kimchi. Food Chem.Toxicol.. 70(7), p.C441-C447 (2005).

46) Kim J. H. et al. Reduction of volatile compounds and off-odor in irradiated ground pork using a charcoal packaging. J. Muscle Foods. 19, p.194-208 (2008).

47) Akram K. et al. Identification and characterization of gamma-irradiated dried lentinus edodes using ESR, SEM, and FTIR Analyses. J. Food Sci.. 77(6), p.C690-C696 (2012).

48) Ahn Jae-Jun. et al. Reliable screening of various foodstuffs with respect to their irradiation status: A comparative study of different analytical techniques. Radiat. Phys. Chem.. 91, p.186-192 (2013).

49) Karam Lisa R.; Simic Michael G.. Ortho-tyrosine as a marker in post-irradiation dosimetry(PID) of chicken. "Health impact. Identification and dosimetry of irradiated food.” Report of WHO working group. Bogl K.W.; Regulla D.F.; Suess M.J. eds. Neuherberg, Munich (Nov.17-21.1986). Copenhagen, WHO, p. 297-304 (1988).

50) Meier W. et al. Analysis of o-tyrosine as a method for the identification of irradiated chicken and the comparison with other methods (Analysis of volatiles and ESR spectroscopy). Radiat. Phys. Chem.. 35, p.332-336 (1990).

51）及川寛ほか. チロシン異性体を指標とした $\gamma$ 線照射冷凍エビの検知. 中央水産研究所報告. 16, p.103-110 (2001).

52) Miyahara M. et al. Identification of irradiation of boned chicken by determination of o-tyrosine and electron spin resonance spectrometry. $J$. Health Sci.. 48(1), p.79-82 (2002).

53) Hayashi $T$. et al. Impedance measurement of irradiated potatoes. J. Food Sci. Technol. Japan. 30, p.51-54 (1983).

54) Glidewell Sheila M. et al. Detection of irradiated food. J. Sci. Food Agric. 61, p.281-300 (1993).

55) Hayashi T.; Todoriki S.. Detection of irradiated peppers by viscosity measurement at extremely high pH. Radiat. Phys. Chem.. 48, p.101-104 (1996).

56) Mei S. et al. Study on rapid detection of irradiated rice based on RVA profile. Nuclear Sci. Techniques. 24, p.040301-1-040301-6 (2013).

57) Kawamura Y. et al. Half-embryo test for identification of irradiated citrus fruit. Radiat. Phys. Chem.. 48(5), p.665-668 (1996).

58) Selvan E.; Thomas P.. A simple method to detect gamma irradiated onions and shallots by root morphology. Radiat Phys Chem.. 55, p.423-427 
(1999).

59) Marín-Huachaca Nélida S. et al. identification of gamma-irradiated papaya, melon and watermelon. Radiat. Phys. Chem.. 71(1-2), p.193-196 (2004).

60) Khawar A. et al. A Germination test: an easy approach to know the irradiation history of seeds. Pak. J. Agri. Sci.. 47(3), p.279-285 (2010).

61) Kume $T$. et al. Immunochemical identification of irradiated chicken eggs. J. the Sci. Food Agric.. 65(1), p.1-4(1994).

62) Tyreman Anne L. et al. Detection of food irradiation by ELISA. Food Sci. Technol. Today. 12(2), p.108-110 (1998).

63) Alam Mohammad K.. Detection of gamma radiation-induced oxidation in animal and bacterial DNA. Bangladesh J. Microbiol., 23(2), p.130-132 (2006).

64) Kikuchi M. et al. Chemiluminescence ELISA for the detection of oxidative DNA base damage using anti-8-hydroxy-2'-deoxyguanosine antibody: application to the detection of irradiated foods. Radioisotopes, 56, p.509-517 (2007).

65) Elliott Christopher T. et al. Detection of irradiated chicken meat by analysis of lipid extracts for 2-substituted cyclobutanones using an enzyme linked immunosorbent assay. Analyst. 120(9), p.2337-2341 (1995).

66) Zhao Y. et al. Development of a competitive indirect enzyme-linked immunosorbent assay based on monoclonal antibodies for the detection ofdodecylcyclobutanone in irradiated beef. J. $A g$ ric. Food Chem.. 61(32), p.7749-7753 (2013).

67) Kizil R. et al. Characterization of irradiated starches by using FT-raman and FTIR spectroscopy. J. Agric. Food Chem.. 50 (14), p.3912-3918 (2002).

68) Shao Y. et al. Infrared spectroscopy and chemometrics for the starch and protein prediction in irradiated rice. Food Chemistry. 126(4), p.1856-1861 (2011).

69) Badr Hesham M.. Infrared spectroscopy for the detection of irradiated meats. Journal of Ameri- can Science. 8(6), p.208-214 (2012).

70) Liu Hai J. et al. Analysis and identification of irradiated spirulina powder by a three-step infrared macro-fingarprint spectroscopy. Radiat. Phys. Chem.. 85, p.210-217 (2013).

71) Kong W. W. et al. Irradiation dose detection of irradiated milk powder using visible and near-infrared spectroscopy and chemometrics. J. Dairy Sci.. 96(8), p.4921-4927 (2013).

72) Stefanova R. et al. H-NMR spectroscopy as an alternative tool for the detection of $\gamma$-ray irradiated Meat. Food Analytical Methods. 4, p.399-403 (2011).

73) Zoumpoulakis P. et al. A combined methodology to detect $\gamma$-irradiated white sesame seeds and evaluate the effects on fat content, physicochemical properties and protein allergenicity. Food Chem.. 131, p.713-721 (2012).

74) Ribeiroa Abene S. et al. Discriminating gammairradiated soybean seeds by $1 \mathrm{H}$ NMR-based metabonomics. Food Control. 36(1), p.266-272 (2014).

75）関口正之ほか。魚及び魚エキスを用いた調味料 の放射線照射履歴の検知一食品より分離した鉱 物質の TL 分析と適用上の配慮事項-。東京都 立産業技術研究センター研究報告. 4, p.24-27 (2009).

76) Ahn Jae-Jun et al. Effectiveness of luminescence analysis to identify gamma-irradiated shrimps: Effects of grinding, mixing and different methods of mineral separation. Food Research Inter national. 54(1), p.416-422 (2013).

77）農林水産消費安全技術センター。食と農のサイ エンス〜飼料の鑑定〜その(2). 大きな目小さな 目. 19, p.6-7 (2010).

78) WHO. "WHO Infection control guidelines for transmissible spongiform encephalopathies." Report of a WHO consultation geneva, Switzerland, 23-26 March 1999, WHO/CDS/CSR/ APH/2000.3, Annex III (2000).

79) Akram Ahn K. et al. Identification of irradiated shellfish using well-characterized thermoluminescence properties of biogenic minerals pres- 
ent in the exoskeletons. Food Analytical Methods. 6(5), p.1345-1352 (2013).

80）関口正之ほか. 健康食品の放射線照射履歴の検 知-有機酸カルシウム及びその原料-. 食品照射. 48 (1)， p.24-30 (2013).

81）関口正之ほか.グルコサミンを含む錠剤の照射 履歴検知. 東京都立産業技術研究センター研究 報告. 8, p.42-45（2013）。

82）佐藤信彦. 検查技術 放射線照射食品の検知法 の実際. 冷凍食品技術研究.90, p.25-38(2011).

83) Chen S. et al. Identification of 2-aldylcyclobutanones in nutmeg (Myristica fragrans). Food Chemistry. 134, p.359-365 (2012).

84) Soncina S. et al. Improved determination of 2-dodecylcyclobutanone in irradiated ground beef patties by gas-chromatography massspectrometry(GC/MS) coupled with solid-phase
microextraction(SPME) technique. Food Chem.. 134(1), p.440-4441 (2012).

85）堤智昭ほか。振とう抽出法による放射線照射 した食肉打よびサーモンに打ける2-アルキル シクロブタノン類の検知. 食品照射. 48 (1), p.31-37 (2013).

86) Takahashi K. et al. Rapid analysis of 2-alkylcyclobutanones in irradiated meats, cheese and salmon by direct solvent extraction followed by GPC. Shokuhin Eiseigaku Zasshi. 54(3), p.173-177 (2013).

87) Crews C. et al. Analysis of 2-alkylcyclobutanones for detection of food irradiation: Current status, needs and prospects. J. Food Comp. Anal.. 26(1-2), p.1-11 (2012).

(2014 年 8 月 7 日受理) 